\title{
ESTADO E AUTOCRACIA DA BURGUESIA BRASILEIRA: ESTUDOS DA HISTORIOGRAFIA E DA POLÍTICA
}

\section{Resenha do livro: \\ MAZZEO, Antonio Carlos. Estado e Burguesia no Brasil. Origens da autocracia Burguesa. $3^{\text {a }}$ Ed.- São Paulo: Boitempo Editorial, 2015.}

\section{Resenha por: \\ Maria de Fátima Rodrigues Pereira}

Antonio Carlos Mazeo, autor da obra ora resenhada, fez graduação em Ciências Políticas e Sociais, mestrado em Sociologia e doutorado em História Econômica pela Universidade São Paulo. Seu pós - doutorado foi realizado em Filosofia Política na UniversitàDegli Studi Roma- Tre. É professor de programas de Pós-Graduação e militante político.

Resenha-se a terceira edição, publicação da Boitempo Editorial. A primeira edição publicada pela Oficina de Livros é datada de 1989, a segunda pela Cortez Editora é 1997.

O texto que serve de base às três edições é a dissertação de mestrado do autor, defendida no Programa de Pós-Graduação em Sociologia da Universidade de São Paulo, em 1986, intitulada A gênese da autocracia burguesa no Brasil.

As três edições mantêm o mesmo título- Estado e burguesia no Brasil. Origens da autocracia burguesa, também trazem o texto original, com pequenos arranjos de estilo de uma edição para a outra que deixam mais claras as teses do autor. Porém, a terceira edição, tem dois elementos a mais: Apresentação de José Paulo Netto e um Apêndice, do autor, ao final do livro.

Na Apresentação, José Paulo Netto costura trajetória de Mazzeo como intelectual e militante político do $\mathrm{PCB}$, para salientar a maturidade das contribuições na interpretação do Brasil, em que Estado e Burguesia no Brasil. Origens da autocracia Burguesa, entende, tem lugar privilegiado.

No Apêndice: Notas sobre a Teoria da via Colonial do Desenvolvimento do Capitalismo, Mazzeo esclarece razões das interpretações "formas feudais de produção no continente latino americano", as abordagens marxistas com influências positivistas e decorrências dessas interpretações nas compreensõese práticas políticas no continente latino americano e Brasil, alinha-se à corrente teórico- explicativa próxima a Caio Prado Jr. 
a partir dos textos de Marx e Engels.O Apêndice, não nega as teses da obra já publicadas nesta e nas edições que a precederam, atualiza-as, esclarece-as, pois, Mazzeo entende que "um Livro tem sua própria história, vivida não somente pelo autor, mas também por aqueles que tiveram a paciência de analisá-lo. Como saborosamente advertiu Montaigne, um autor não pode nunca alterar um texto que foi dado ao público, ainda que possa ajustálo em suas interpretações. Assim, faço minhas suas palavras: 'J'adjuste, mais jenecourrigepas"”.

Integra a terceira edição- Prefácio à Terceira Edição- onde é situada a temática da obra- "no produto do amplo debate que se desencadeou na militância comunista, entre as décadas de 1960 e 1970, no contexto do pior momento da ditadura" quando, por conta de se entender o que se passava se estudava e debatia "o caráter do capitalismo brasileiro e de sua burguesia, os fundamentos teóricos e as interpretações marxistas do Brasil, as táticas de resistência à ditadura, as diretrizespolítico- práticas das esquerdas e a ação dos partidos revolucionários na luta pelo socialismo-[...]”. Contribuíam com esses debates, entre outros, os estudos Nelson Werneck Sodré, Caio Prado Jr., Florestan Fernandes, Octavio Ianni, Fernando Novaes, Francisco de Oliveira, Maurício Tragtemberg, Carlos Nelson Coutinho, Leandro Konder, José Chasin, Roberto Schwarz, Emília Viotti. Na Introdução, Mazzeo apresenta o objeto e o faz teoricamente, como apropriado, situando-o na crítica marxista à "teoria consagrada", ao "modo de produção subsidiário", ao "modo de produção escravista colonial". Este rumo lhe permite construir sua tese ao longo dos quatro capítulos: a formação da autocracia burguesa como particularidade da formação social brasileira do modo de produção capitalista “-engendrando uma burguesiaautocrática, sempre pronta a alijaras massas trabalhadoras dos processos políticos do país, através de contrarrevoluções constantes, no sentido de manter inalterado o status quo econômico e político-"

A obra é atualíssima por ajudar a pensar historicamente a conjuntura atual, caracterizada pelo ataque explicito do capital, da burguesia em sua autocracia, também as teorias e métodos e suas finalidades na pesquisa e práticas nomeadamente nas educacionais. Neste sentido esta obra de Mazzeoinscreve-se no enfrentamento a abordagens, fragmentadas e presentistas do real, colabora na compreensão do Estado brasileiro, da burguesia como classe que recompõe seus poderes autocráticos. Além disto, contribui com a história da historiografia brasileira e posiciona-se em polêmicas teóricas da produção historiográfica brasileira que envolveram historiadores, sociólogos, cientistas 
políticos, e partidos políticos, com repercussão nas disputas por projetos de governo do Brasil, no segundo meio século XX e nestas primeiras décadas do XXI.

'Maria de Fátima Rodrigues Pereira é professora do Programa, mestrado e doutorado, da Universidade Tuiuti do Paraná 